\title{
Wear of Posterior Composite Resins
}

\author{
Yoshiaki TANI, Hideaki GOTO and Kazuo IDA \\ Department of Dental Materials, Research Center for Medical Polymers and Biomaterials, Kyoto \\ University Sakyo-ku, Kyoto 606, Japan
}

Received on July 31,1987

Accepted on September 30, 1987

\begin{abstract}
In vitro wear of sixteen posterior composite resins was determined by the glass beads abrasion test. The wear was remarkably greater with the thick slurry than with the thin slurry. Microfilled posterior composites were higher wear-resistant than highly loaded and blended posterior composites. There is little difference in wear between submicrofilled resins and microfilled resins with the thick slurry. This suggests that the filler particle size is relatively important to wear resistance of the posterior composite material. There was a close parallel between the results of the glass beads abrasion test and clinical observations. There is no consistency among the wear measurements in the toothbrushing abrasion test.
\end{abstract}

Key words: Posterior Composite, Abrasion Resistance, Wear Test

\section{INTRODUCTION}

Wear resistance and marginal fracture toughness are the two most important properties of the composite restorative materials for posterior teeth. The test method to evaluate these properties, moreover, must be reflected in clinical evaluation.

The results of our glass beads abrasion test ${ }^{1)}$ showed a close parallel to clinical findings in the composite restoration. The composite resin developed originally as the anterior restorative material has been progressively improved in its mechanical and physical properties enough to endure various stresses. The recently developed posterior composite tends to be more highly loaded, and it blended fillers with a wide range of distribution in particle size.

The purpose of the present investigation was to determine the wear of sixteen commercially available posterior composites by the glass beads abrasion test reported previously.

\section{MATERIALS AND METHODS}

Materials evaluated for abrasion resistance in this study consisted of five chemical-cured posterior composites and eleven visible light-cured posterior composites. Batch numbers and manufacturers for all materials tested are given in Table 1. Isomolar, Heliomolar and Heliomolar Radiopaque are microfilled composites. Palfique and Palfique Light are submicrofilled composites which are filled with about $70 \mathrm{wt}$ \% of spherical silica particles of the filler $0.2-0.3 \mu \mathrm{m}$ in diameter of uniform size ${ }^{2}$. Palfique has sufficient strength for restoration of posterior teeth and excellent esthetic appearance for anterior teeth ${ }^{3)}$. Bell Firm $\mathrm{P}$ is filled ground silicon nitride $\left(\mathrm{Si}_{3} \mathrm{~N}_{4}\right)$ and $\alpha$-quartz in the amount of $80 \mathrm{wt} \%$ in matrix resin (tetramethylol methane trimethacrylate and tetramethylol methane tetramethacrylate $)^{4}$. Sinter Fil is filled with microfillers and with agglomerated microfiller 
Table 1 Materials tested

\begin{tabular}{lll}
\hline \multicolumn{1}{c}{ Material } & Batch Number & Manufacturer \\
\hline Chemical-cured & & \\
Clearfil Posterior & PU2216, PC2116 & Kuraray \\
Bell Feel & $17 \mathrm{E} 48$ & Kanebo \\
P-10 & A : 5B1, B : 5D2 & 3 M \\
Palfique & U743, C300 & Tokuyama Soda \\
Isomolar & $3182.01,3134.03$ & Vivadent \\
Light-cured & & \\
Estilux Posterior & 167 & Kulzer \\
Ful-fil & 1016854 & Caulk-Dentsply \\
P-30 & 6 P1 & 3 M \\
Occlusin & LH06 & ICI \\
Lite Fil P & 068561 & Shofu \\
Photo Clearfil A & HAS-1007 & Kuraray \\
Pyrofil Light Bond & $169-005 S$ & Sankin \\
Palfique Light & LU213 & Tokuyama Soda \\
Sinter Fil & 41071 & Teledyne Getz \\
Heliomolar & 317702 & Vivadent \\
Heliomolar Radiopaque & 337601 & Vivadent \\
\hline
\end{tabular}

complexes prepared by sintering the microfillers. The other nine materials may generically be called highly loaded composites.

Five specimens $(10 \times 10 \times 1.5 \mathrm{~mm})$ of each material were prepared after mixing according to the manufacturers' instructions. Specimens of light-cured posterior composites were

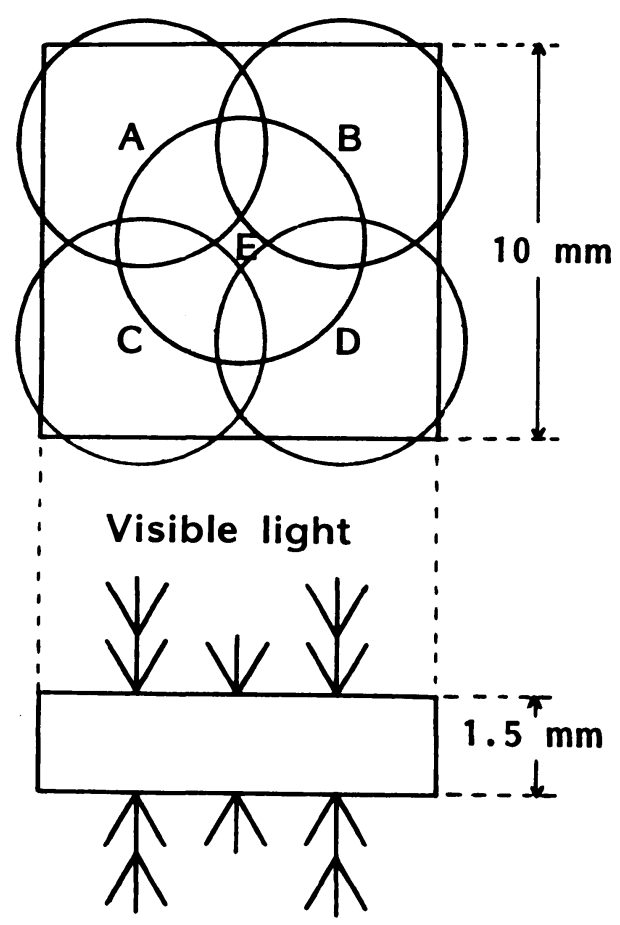

Fig. 1 Schematic drawing of specimen and positions of visible light exposure. 
exposed to light emitted by Optilux* with five 10-second exposures on both the upper and lower sides of the specimen through a plastic sheet (Fig. 1).

All specimens were polished with a 1200-grit silicon carbide paper to wear away $200 \mu \mathrm{m}$ in thickness from the surface and then cleaned with an ultrasonic cleaner ${ }^{* *}$ for $10 \mathrm{~min}$. After these specimens were kept in a desiccator until they attained a constant weight, specific gravity of each material was measured with a specific gravity meter for solid material***, prior to one week storage in $37^{\circ} \mathrm{C}$ water.

The detailed procedures for the glass beads abrasion test were demonstrated in a previous paper ${ }^{11}$. A schematic diagram of the glass beads abrasion test apparatus in shown in Fig. 2.

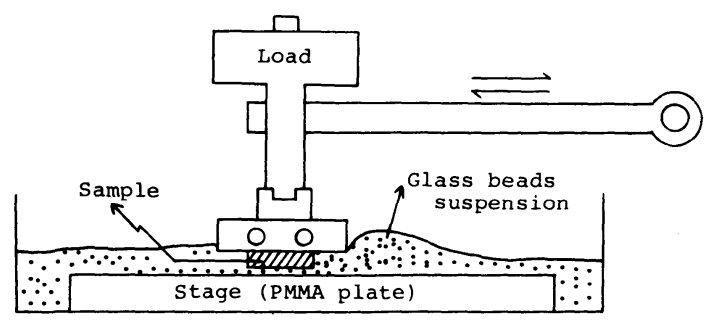

Fig. 2 Schematic diagram of the glass beads abrasion test apparatus.

Two types of slurry were prepared. One (standard slurry) was mixed with $140 \mathrm{~g}$ of glass beads \# to $100 \mathrm{ml}$ water, and the other was mixed with $280 \mathrm{~g}$ of the same glass beads to 100 $\mathrm{ml}$ water. The intermediate particle size of the glass beads is 18 with a particle size distribution ranging from several $\mu \mathrm{m}$ to about $30 \mu \mathrm{m}$. The slurry was spread over the PMMA plate stage. The specimen, fixed in the horizontal drive arm, was reciprocated with a $400 \mathrm{~g}$ load of glass beads at a velocity of 60 strokes per minute for 10,000 times, which is equivalent to traveling $1,000 \mathrm{~m}$. The degree of wear was measured by weight loss, later converted to volume loss with specific gravity.

The conventional toothbrushing abrasion test was also carried out for comparison. In preparing the abrasive slurry, $150 \mathrm{~g}$ of tooth paste \# was added to water to make a total volume of $500 \mathrm{ml}$. The specimen was reciprocated with a $250 \mathrm{~g}$ load on a hard tooth brush which was connected to five other tooth brushes \#\# in series with the slurry.

\section{RESULTS AND DISCUSSION}

The results obtained for the wear caused by the glass beads abrasion test are shown for all materials in Table 2 and Fig. 3 and 4.

* Demetron Research Corporation, Danbury, Conn., U. S. A.

** Transister / Ultrasonic T-9, L and R Mfg., Co., New Jersey, U. S. A.

*** S-280, Shimadzu Corporation, Kyoto, Japan.

\# EGB-731, Toshiba-Ballotini Co., Ltd., Tokyo, Japan.

\# Lark Sunstar, Sunstar Inc., Takatsuki, Japan.

\#\# Perio-II-H, Sunstar Inc., Takatsuki, Japan. 
Table 2 Wear of posterior composites after glass beads abrasion test in the different rate of water, to glass beads

\begin{tabular}{lrrr}
\hline \multicolumn{1}{c}{ Material } & \multicolumn{2}{c}{ Ratio of water to glass beads } & $\begin{array}{c}\text { Specific } \\
\text { gravity }\end{array}$ \\
\cline { 2 - 3 } & $100 \mathrm{ml} / 140 \mathrm{~g}$ & $100 \mathrm{ml} / 280 \mathrm{~g}$ & 2.094 \\
Clearfil Posterior & $2.67(0.14)$ & $26.36(3.01)$ & 2.365 \\
Bell Feel & $4.27(2.03)$ & $31.04(1.56)$ & 2.198 \\
P-10 & $10.69(2.36)$ & $35.53(0.14)$ & 1.734 \\
Palfique & $4.15(0.40)$ & $13.38(1.67)$ & 1.600 \\
Isomolar & $0.75(0.38)$ & $10.88(1.56)$ & 2.062 \\
Estilux Posterior & $7.56(0.69)$ & $34.00(4.03)$ & 2.204 \\
Ful-fil & $5.81(1.23)$ & $28.63(4.22)$ & 2.269 \\
P-30 & $6.83(0.84)$ & $33.23(9.87)$ & 2.428 \\
Occlusin & $11.28(3.12)$ & $38.51(9.95)$ & 1.992 \\
Lite Fil P & $10.14(0.59)$ & $28.46(4.17)$ & 2.201 \\
Photo Clearfil A & $3.63(0.47)$ & $24.99(3.09)$ & 2.184 \\
Pyrofil Light Bond & $2.19(0.27)$ & $35.90(6.96)$ & 1.761 \\
Palfique Light & $3.12(1.36)$ & $18.29(8.06)$ & 1.729 \\
Sinter Fil & $4.45(0.75)$ & $32.04(4.80)$ & 1.621 \\
Heliomolar & $0.31(0.10)$ & $5.37(0.12)$ & 1.868 \\
Heliomolar Radiopaque & $0.43(0.37)$ & $8.73(2.94)$ & \\
\hline
\end{tabular}

Wear is expressed in volume loss $\left(\mathrm{cm}^{3} \times 10^{-3}\right)$.

Parentheses indicate standard deviation.

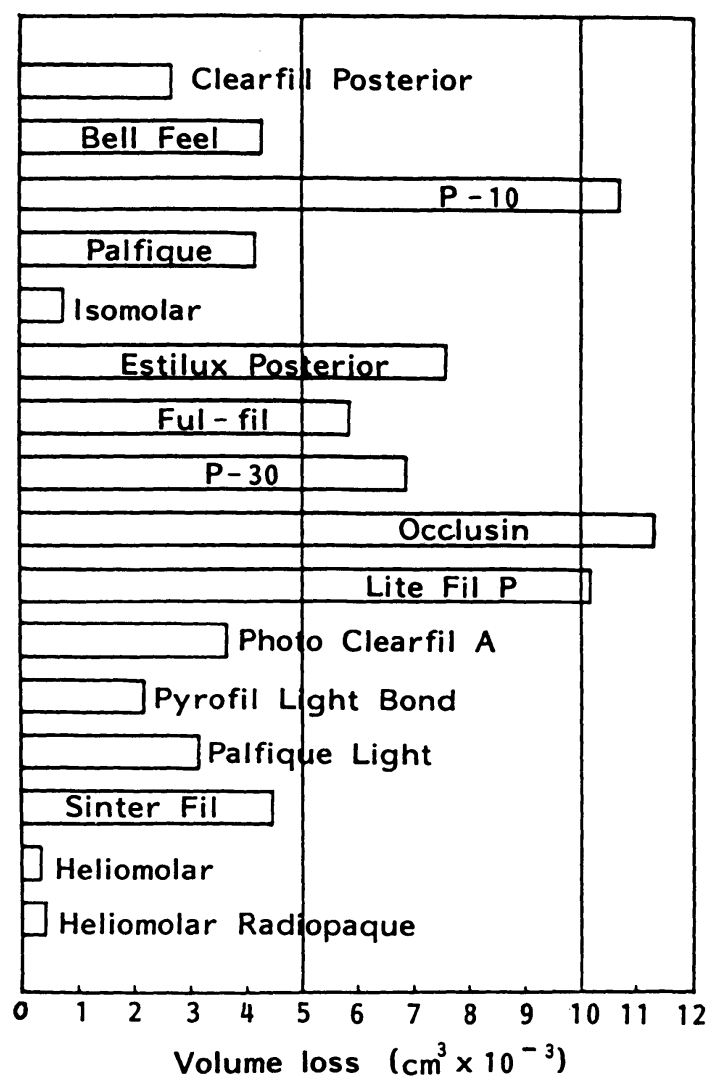

Fig. 3 Wear of posterior composites after glass beads abrasion test in the ratio of 100 $\mathrm{ml}$ water to $140 \mathrm{~g}$ glass beads. 


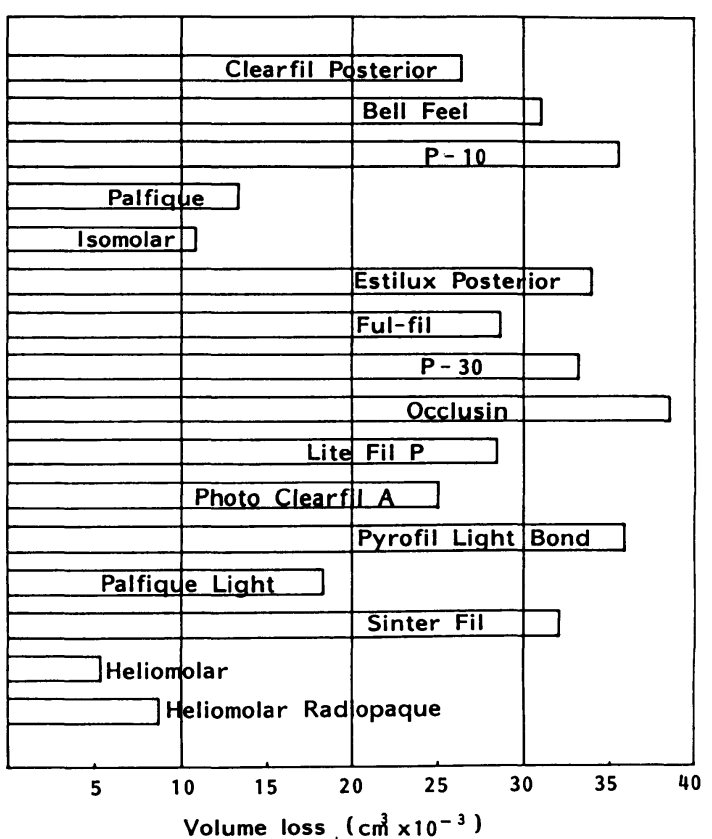

Fig. 4 Wear of posterior composites after glass beads abrasion test in the ratio of 100 $\mathrm{ml}$ water to $280 \mathrm{~g}$ glass beads.

Thg wear under the standard test condition (in the rate of $100 \mathrm{ml}$ water to $140 \mathrm{~g}$ glass beads) was minimal with Heliomolar, Heliomolar Radiopaque and Isomolar, and followed in increasing order by Pyrofil Light Bond, Clearfil Posterior, Palfique Light, Photo Clearfil A, Palfique. Occlusin, P-10 and Light Fil P showed the greatest wear. The wear was remarkably greater with the thick slurry than with the standard slurry. The wear was minimal with Heliomolar, Heliomolar Radiopaque, Isomolar and Palfique, nevertheless, Occlusin, P-10 showed the greatest wear. It is noteworthy that much greater wear was shown with Pyrofil Light Bond and Clearfil Posterior, which showed considerable little wear in thin glass beads slurry.

From the date presented in this study, microfilled posterior composites were much higher wear-resistant than highly loaded and blended posterior composites, which are popularly known as the hybrid composites. There is little difference in wear between submicrofilled resins and microfilled resins with the thick slurry. This is suggests that the filler paticle size is relatively important to wear resistance of the posterior composite material.

Figure. 5 shows the SEM photograph of the surfaces of specimens after the glass beads abrasion test. On the left in the photograph is Heliomolar which showed the least wear and on the right is Occlusin which showed the greatest wear. Fig. 6 shows a SEM photograph of a lower second molar restored with a highly loaded blend-type composite resin (Occlusin). Fig. 7 shows a SEM photograph of two second molars restored with the only submicrofilled composite resin (Palfique).

Our results in this study, that the wear level of the microfilled composite was smaller 

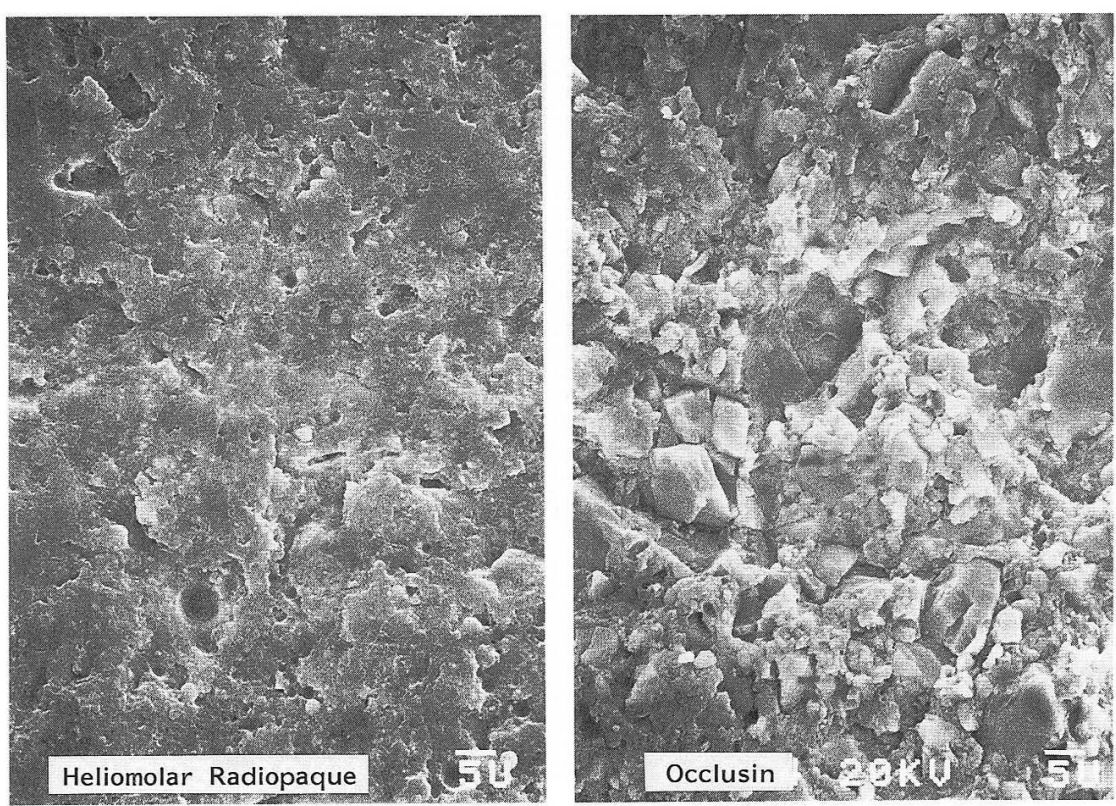

Fig. 5 Comparative wear of surfaces of Heliomolar Radiopaque (left) and Occlusin (right) after glass beads abrasion test with thin slurry. (Orig. mag. $\times 1000$ ).
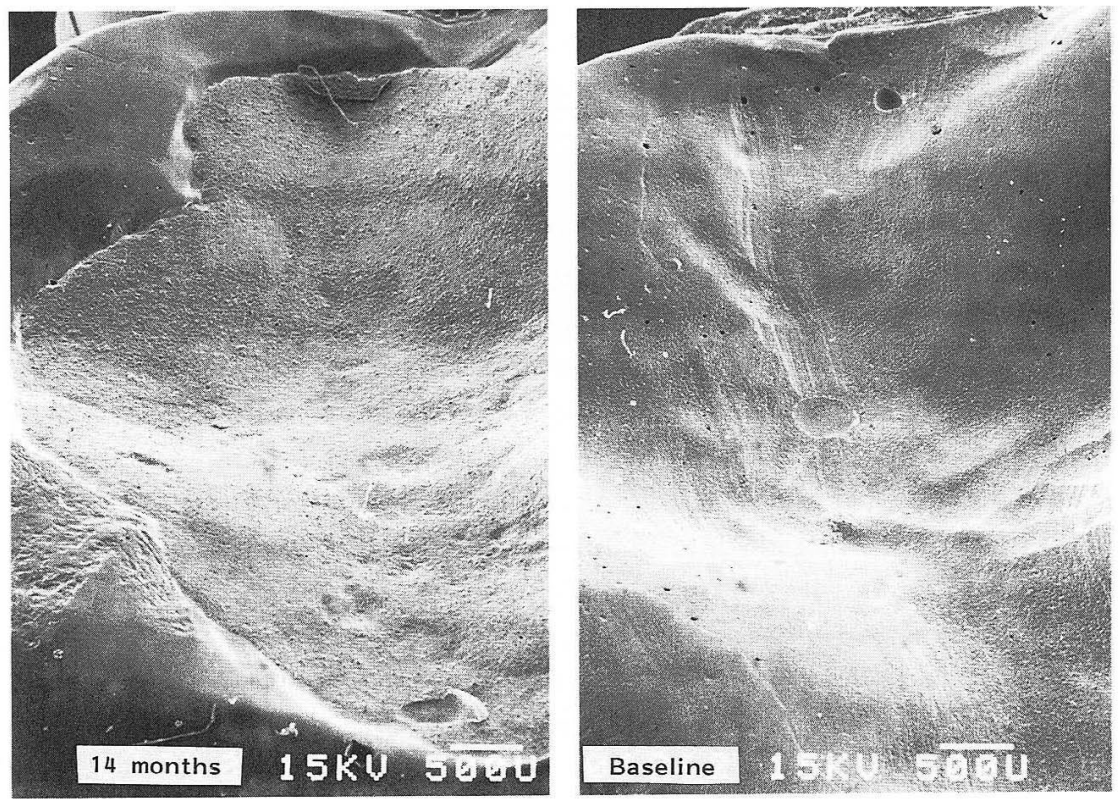

Fig. 6 Scanning electron photomicrographs of a lower second molar restored with Occlusin after 14 months (left) and baseline (right). 

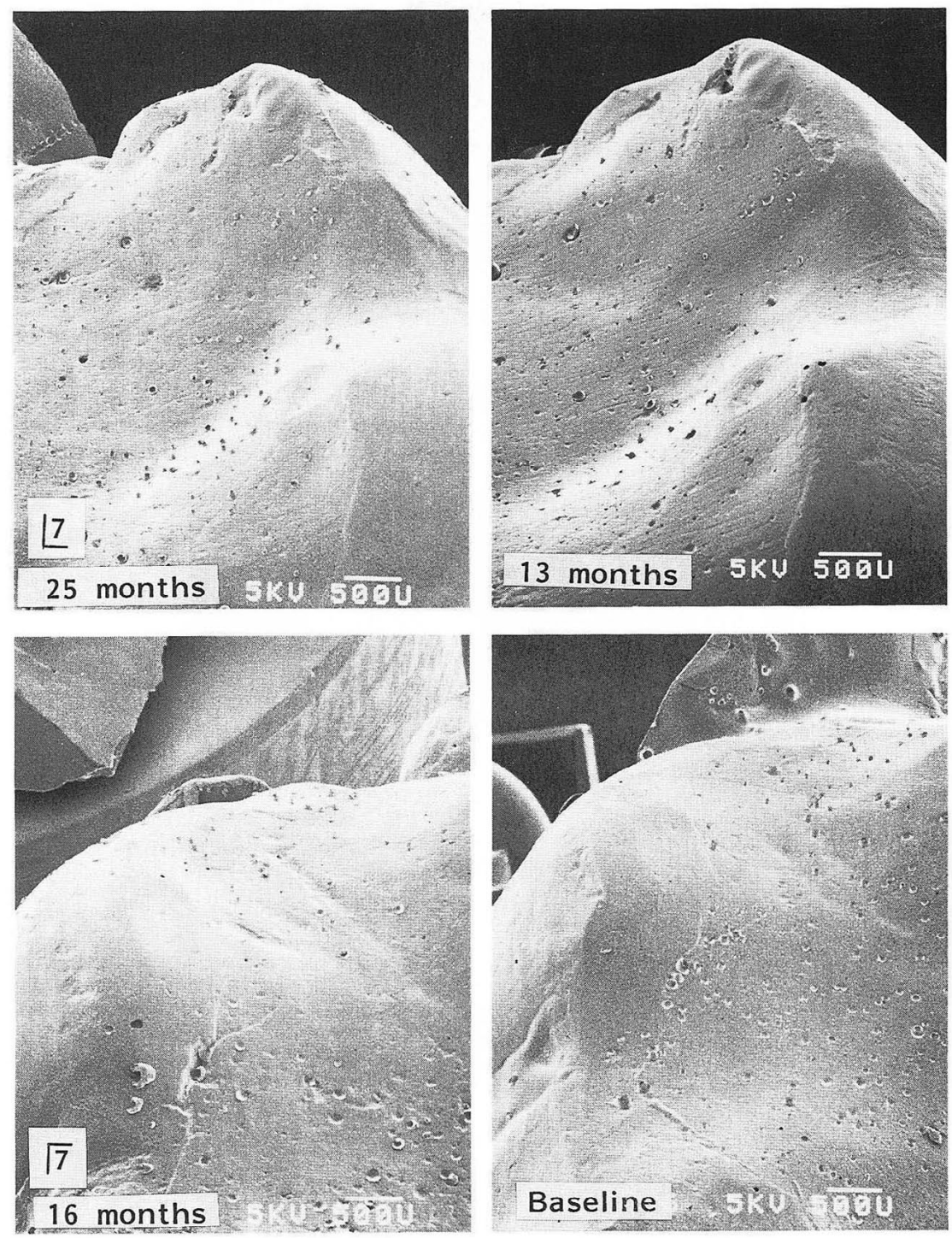

Fig. 7 Scanning electron photomicrographs of two cases of Palfique restorations in molar teeth.

than the other composite, agreed with other reports ${ }^{5-7)}$. Sinter Fil is filled with microfillers and with agglomerated microfiller complexes prepared by sintering the microfillers. It was confidently expected that Sinter Fil would show favorable wear resistance due to tight bonding by the infiltration of organic matrixes and by wealth in the retention sites. The wear of Sinter Fil after the glass beads abrasion test, contrary to expectation, was much the same as the highly loaded blend-type posterior composites. It is possible that the sintering of microfillers lost characteristic as a microfiller and exposed its characteristic as a coarse filler. A Sinter Fil restoration exhibiting severe localized deterioration after 2 years is illustrated 


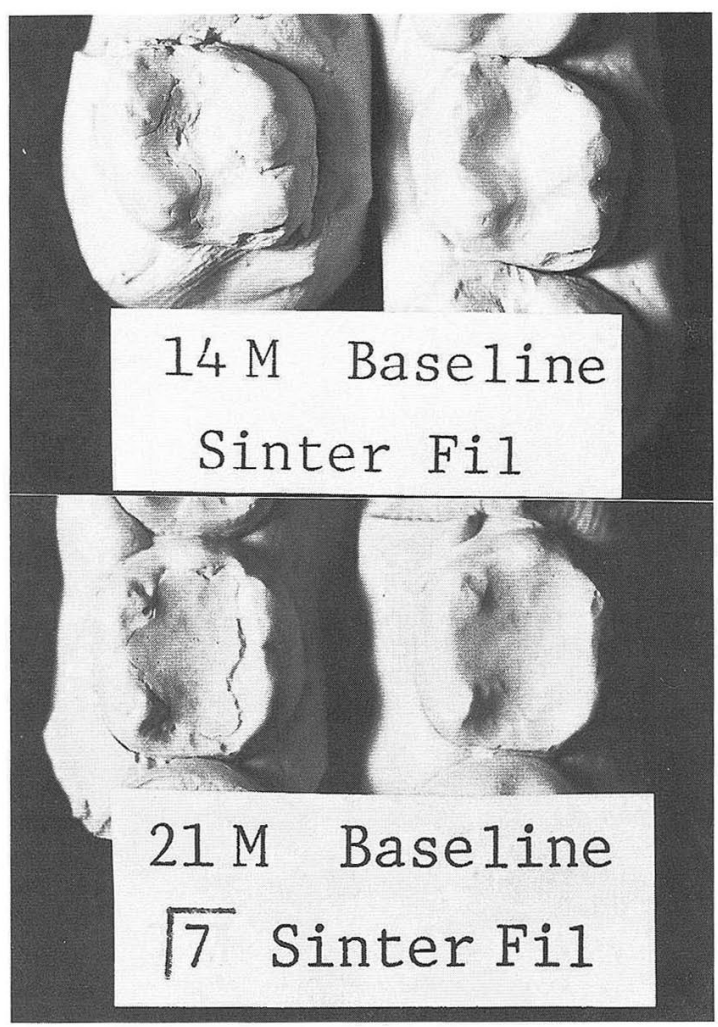

Fig. 8 Stone dies of two cases of Sinter Fil restorations in molar teeth.

Table 3 Wear of posterior composites after toothbrushing abrasion test

\begin{tabular}{lc}
\hline \multicolumn{1}{c}{ Material } & $\begin{array}{r}\text { Volume loss } \\
\left(\mathrm{cm}^{3} \times 10^{-3}\right)\end{array}$ \\
\hline Clearfil Posterior & $0.110(0.091)$ \\
Bell Feel & $0.085(0.042)$ \\
P-10 & $0.150(0.055)$ \\
Palfique & $0.173(0.115)$ \\
Isomolar & $0.331(0.181)$ \\
Estilux Posterior & $0.131(0.056)$ \\
Ful-fil & $0.045(0.045)$ \\
P-30 & $0.339(0.066)$ \\
Occlusin & $0.111(0.049)$ \\
Lite Fil P & $0.186(0.029)$ \\
Photo Clearfil A & $0.123(0.055)$ \\
Pyrofil Light Bond & $0.060(0.027)$ \\
Palfique Light & $0.114(0.057)$ \\
Sinter Fil & $0.463(0.058)$ \\
Helimolar & $0.105(0.142)$ \\
\hline
\end{tabular}

Parentheses indicate standard deviation. 
Table 4 Wear of several restorative materials after brushing abrasion test

\begin{tabular}{lcc}
\hline Type of restoratives & \multicolumn{2}{c}{ Type of water suspension* } \\
\cline { 2 - 3 } & Water & Water +10\% Glycerin \\
\hline $\begin{array}{l}\text { Unifilled MMA resin } \\
\quad \text { (Sevriton) } \\
\text { Microfilled resin } \\
\quad \text { (Silar) }\end{array}$ & $0.37(0.10)$ & $0.28(0.40)$ \\
$\begin{array}{l}\text { Submicrofilled resin } \\
\text { (Palfique) }\end{array}$ & $1.49(0.26)$ & $2.14(1.89)$ \\
$\begin{array}{c}\text { Conventional composite } \\
\quad \text { (Clearfil F 1l) }\end{array}$ & $0.17(0.05)$ & $0.32(0.23)$ \\
$\begin{array}{l}\text { Highly-loaded composite } \\
\text { (Clearfil Posterior) } \\
\text { High copper amalgam } \\
\text { (Spherical D) }\end{array}$ & $0.34(0.04)$ & $0.53(0.02)$ \\
\hline
\end{tabular}

Wear is expressed in volume loss $\left(\mathrm{cm}^{3} \times 10^{-3}\right)$.

Parentheses indicate standard deviation.

* For preparing the abrasive slurry, $150 \mathrm{~g}$ of toothpaste was added water suspension to make

a total volume of $500 \mathrm{ml}$.

in Fig. 8. This is similar to the finding of a microfilled composite of agglomerated silica demonstrated by Heymann et $a l^{8)}$.

The present study amply demonstrated that the results obtained by the glass beads abrasion test were in accord with clinical findings for occlusal wear.

The results for wear, caused by the toothbrushing abrasion test, are shown in Table 3 . There is no particular tendency in wear among the posterior composites. Table 4 compares the wear of several different restorative materials after toothbrushing abrasion test. Amalgam showed the least wear, and microfilled resin showed the most. The conventional composite was better than the microfilled resin. The results were not consistent with the clinical results.

\section{CONCLUSION}

Wear resistance of sixteen posterior composites was evaluated by the glass beads abrasion test. From the date presented in this study, microfilled and submicrofilled posterior composites were more superior in wear resistance than the highly loaded posterior composites. This suggests that the filler particle size is relatively important to wear resistance of the posterior composite material. There was a close parallel between the results of the glass beads abrasion test and clinical observations. Moreover, SEM studies supported the results described above.

(This study was supported in part by Grant-in-Aid for Scientific Research 1986 (B-61480405), from the Ministry of Education, Science and Culture, Japan.)

\section{REFERENCES}

1) Tani, Y., Suzuki, K. and Yuasa, S. : A New Method for Measuring the Wear of Composite Restorative Materiale, Dent Mater J 2 (1): 124-133, 1983. 
2) Tani, Y., Nambu, T., Kawamura, T., Kusumoto, K., Yuasa, S. and Suzuki, K. : Mechanical Properties and Surface Characteristics of a New Composite Resin "TC". 78th General Session, Japanese Society of Conservative Dentistry, Abstract No. 49, April, 1983. (in Japanese)

3) Tani, Y., Nambu, T. and Kawamura T. : Surface Characteristics of a New Composite Resin "TC", $J$ $J$ Dent Mat 2 (5) : 604-608, 1983. (in Japanese)

4) Kawahara, S., Imanishi, Y., Takeda, S., Oshima, H., Makita, T., Kudo, S. and Funakoshi, T. : A New Composite Resin of TMM (M)-Si ${ }_{3} \mathrm{~N}_{4}$ for De-amalgam in Dentistry, Dent Outlook 58 (2) : 359-370, 1981. (in Japanese)

5) Knudsen, M. B. and Jørgensen, K. D. : Abrasion of Microfill Restorative Resins in Class 1 Cavities, Scand J Dent Res 91: 159-161, 1983.

6) Mitchem, J.C. and Gronas, D. G.: The Continued in vivo Evaluation of the Wear of Restrative Resins, J A D A 111 : 961-964, 1985.

7) Kai, M., Satou, J., Satou, N., Shintani, H. and Fujioka, M. : Sliding Wear of Variuos Composite Resins and Bovine Enamel, Dent Mater J 5 (2): 165-171, 1986.

8) Heymann, H. O., Wilder, Jr., A. D., May, Jr., K. N. and Leinfelder, K. F. : Two-year Clinical Study of Composite Resins in Posterior Teeth, Dent Mater 2: 37-41, 1986. 


\section{臼歯用コンポジットレジンの耐摩耗性 \\ 谷 嘉明, 後藤秀明, 井田一夫 \\ 京都大学医用高分子研究センター歯科材料応用研究部門}

臼歯用修復材としての諸物性のうち, 耐摩耗性および marginal fracture toughness は臨床的にきわめて重要 である。しかも，それらの評価法は臨床結果を反映し， 予測できるものでなければならない。筆者らの考案した グラスピーズ摩耗試験が臨床の結果と比較的良好な一致 性を示すことを確認したが，今回，本試験法を用いて， 市販の 16 種類の臼歯用コンポジットレジンの耐摩耗性 を評価した。

その結果，超微粒子フィラー配合型が，もっともすぐ
れた耐摩耗性を示し, 次いでサブミクロンフィラー配合 型が良好で, 高密度充填型はおおむね摩耗が大きいこと がわかった。このことから, 超微粒子フィラーと粒径数 $\mu \mathrm{m} の$ fine fillers とが混合された高密度充媜型でも含有 しているフィラーのサイズが大きければ, 摩耗が大きい ことが示唆され，そのことは臨床症例の所見によっても 確かめられた。今回, 同時に行ったハブラシ摩耗試験の 結果には，一定の整合性がなく，そのデー夕にはとくに 意味を見出せなかった。

\section{多孔性 Zr-Ti インプラントの空孔の形状と機械的性質}

\section{奥野 攻, 柴田直幸, 三浦維四 \\ 東京医科菌科大学医用器材研究所}

多孔材の空孔には骨が成長侵入し, 強固な結合が得ら れるが，このような多孔材の強度は一般に低いのが問題 であった。そこでジルコニウムとチタンの球形粒子を良 く混合し,焼結して得られる高強度の多孔材を開発した。 粒径を変えて多孔性 $60 \mathrm{wt} \% \mathrm{Zr}-40 \mathrm{wt} \% \mathrm{Ti}$ 合金を作製 し, 空孔の形状寸法, 多孔率と機械的性質を調べ, 歯科 用インプラントとしての可能性を検討した。空孔径や多 孔率から 200〜250 $\mu \mathrm{m}$ の粒子の多孔体でも骨組織の成 長が可能と考えられた。圧縮強さは曲げ強さの約 2 倍で,
小粒子径による多孔体の方が高い強さを示した。圧縮強 さや曲げ強さは骨よりかなり高かった。弾性率も同様に 小粒子による多孔体ほど高かった。弾性率は度質骨と同 じ範囲であり, 骨と力学的にも適合性の良いことが分 かった。圧縮疲労強度は $420 \sim 510 \mu \mathrm{m}$ の粒径の多孔体で $60 \mathrm{MPa}, 250 \sim 300 \mu \mathrm{m}$ の粒径の多孔体で $100 \mathrm{MPa} て ゙$, 臼歯用インプラントとして十分な疲労強さと考えられ た。

\section{多孔性 Zr-Ti インプラントへの骨の成長侵入と軟組織の反応 \\ 柴田直幸, 奥野 攻 \\ 東京医科歯科大学医用器材研究所}

多孔性 Zr-Ti 合金がインプラント材として十分な機 械的性質をもつことを先に報告した。ここでは 3 種の粒 子径の多孔材 (250-300 $\mu \mathrm{m}, 350-420 \mu \mathrm{m}, 500-590 \mu \mathrm{m})$ を家鬼の大腿骨に埋入し骨の成長侵入について検討し た。埋入後, 2 週, 4 週, 8 週, 12 週で屠殺し試料を含 む大腿骨を摘出し押出し試験および組織観察を行った。
骨の成長侵入は 2 週から，4 週にかけてかなり上昇し， 4 週以降緩やかな上昇がみられた。押出し強さも同様な 傾向が見られた。粒子径の大きなものほど押出し強さは 高く, $27 \mathrm{MPa}$ ぐらいの高い值を示した ( 4 週以降)。 $\mathrm{Zr}$ - Ti 多孔材と骨は大部分直接接しており生体親和性は きわめて良好であると思われた。 